\title{
Dzieje siedziby Jacobsona w Warszawie w drugiej połowie XVIII i na początku XIX w.
}

\begin{abstract}
Słowa kluczowe: Warszawa, mieszczaństwo, architektura, XVIII wiek
Key words: Warsaw, Middle class, architecture, 18th century
\end{abstract}

Warszawa uważana jest w piśmiennictwie przedmiotu za miasto typu rezydencjonalnego. Słusznie podkreśla się rolę dworu królewskiego i siedzib magnackich jako czynnika wpływającego na ukształtowanie i zabudowę miasta, wytwarzającego zapotrzebowanie na określone usługi i towary oraz zwiększającego liczbę służby wśród mieszkańców ${ }^{1}$.

Przebywający czasowo w stolicy przedstawiciele bogatej szlachty chętnie tworzyli jurydyki. W XVIII stuleciu było ich $21^{2}$. Leszno, którego nazwa odwoływała się wprost do rodowej siedziby Bogusława i Jana Leszczyńskich, było pierwszą magnacką jurydyką założoną tuż poza granicami obu miast warszawskich. Powstała w 1648 r. między rolą Świętokrzyską a wygonem Starego Miasta. Szerokość tego gruntu, ok. 300 łokci, wymusiła nietypowy układ ulic i zabudowy, bez wydzielonego rynku ${ }^{3}$ Założenie jurydyki było jednym z elementów podkreślania roli rodu Leszczyńskich w mieście i jego okolicach. W 1654 r. podskarbi i podkanclerzy koronny Bogusław stał się też właścicielem Milanowa, Błonia i Kempy oraz Służewca i kilku innych podwarszawskich wsi ${ }^{4}$. Po Leszczyńskich od roku 1737 właścicielami jurydyki Leszno byli Potoccy, a ostatnim był przedsiębiorczy Prot Potocki. Nieruchomości na Lesznie w drugiej połowie XVIII w. posiadali także inni magnaci, m.in. podkomorzy koronny Wincenty Potocki, a po nim Ignacy Działyński (nr hipoteczny 661 i 662), biskup żmudzki Jan Stefan Giedroyć (nr hipoteczny 720), Stanisław Potocki (nr hipoteczny 673), Dwernicki (nr hipoteczny 701)5. Do Album civile z lat 1765-1790 wpisano łącznie 185 osób. Większość nowych obywateli Leszna pochodziła z krajów niemieckich — 90 osób (z Saksonii 30, z Prus 22, ze Śląska 12), a pozostałe 72 wywodziły się z różnych dzielnic Rzeczypospolitej (w tym 17 z Wielkopolski) ${ }^{6}$.

W jurydyce odnotowano wielu rzemieślników różnych profesji. Najwięcej, bo 47, było szewców, a dalej krawców - 32, rzeźników - 23, złotników - 19 i piekarzy - $18^{7}$. Oprócz przekupniów i drobnych kupców na Lesznie mieszkali także kupcy, którzy utrzymywali kontakty handlowe z zagranicą. Byli to: Beniamin Kabs, Jan Henryk Peters, Daniel Kuntze i Karol

1 Wojtowicz J. 2017, s. 121 i n.; Grochulska B. 1980, s. 21 i n.

2 Zostały one zlikwidowane w 1791 r., Sawicki T. 1925, s. 12.

3 Rejman Z. 1985, s. 62-66.

${ }^{4}$ Co do Milanowa data jest nieznana. Podwarszawskie dobra szlacheckie skupowali także przedstawiciele innej gałęzi tego rodu — prymas Andrzej, wojewodowie podlascy Wacław i Stefan, por. Smoleńska B. 1984, s. 96.

\footnotetext{
5 Dziewulski S., Radziszewski H. 1913, s. 368.

${ }^{6}$ Rejman Z. 1985, s. 100.

7 Rejman Z. 1985, s. 102 i n.
} 


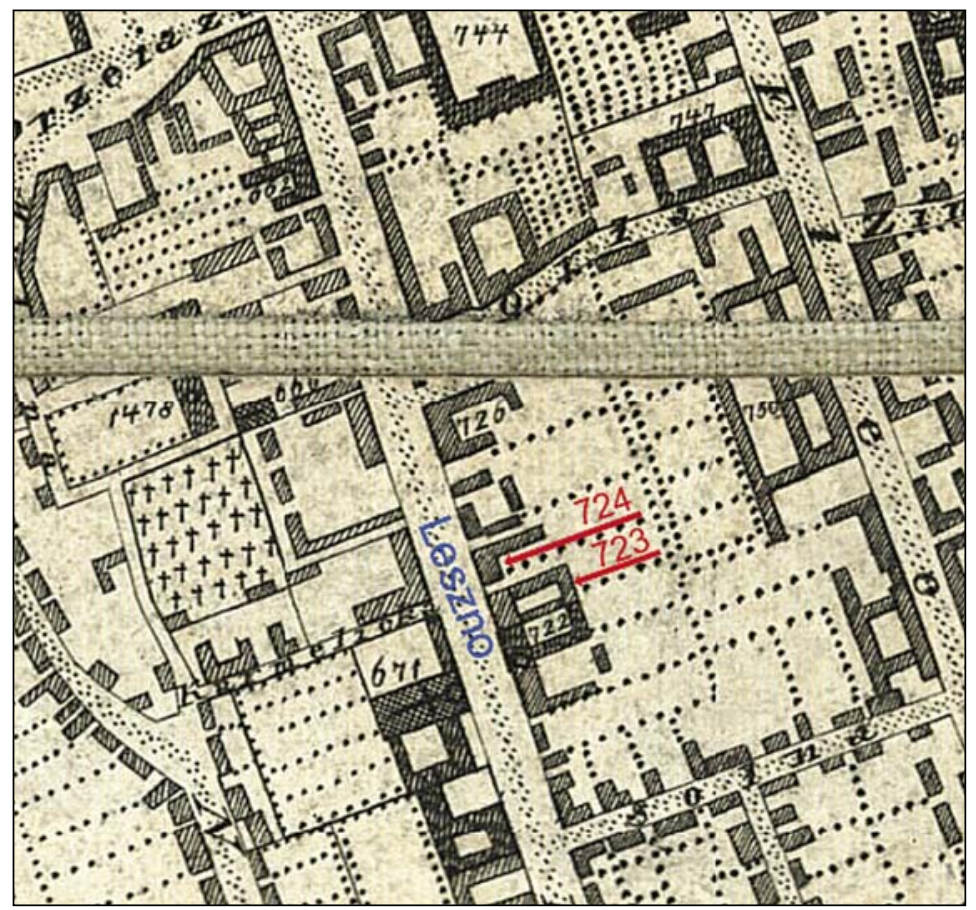

Ryc. 1. Fragment planu miasta Warszawy z 1809 r., za: J.G. Lechman, I. Bach 1809;

Biblioteka Narodowa, sygn. ZZK 20305.

Na czerwono zaznaczono usytuowanie budynków na działkach hipotecznych numer 723-724 należących do rodziny Jacobsonów

Fig. 1. Detail of the map of Warsaw (1809), after: J.G. Lechman, I. Bach 1809; Biblioteka Narodowa, sygn. ZZK 20305.

Red: buildings on the land lots no. 723-724 belonging to the Jacobson Family

Fryderyk Dangiel. W mniejszej znacznie skali prowadzili swe interesy handlowe: Christian Królczyk, Daniel Andres, Bogumił Fiszel i Samuel Hoffman ${ }^{8}$. W takim środowisku zdecydował się osiąść jubiler Joachim Fryderyk Jacobson, do którego należały w drugiej połowie XVIII w. nieruchomości o numerach hipotecznych 723 i 724.

Na terenie Leszna w 1708 r. było 46 posesji. Na planie rosyjskim Warszawy z 1732 r. widoczna jest ulica Leszno z zaznaczonym kościołem karmelitów trzewiczkowych, a niemal naprzeciwko usytuowany jest budynek Jacobsonów. Za Markiem Kwiatkowskim sądzimy, że był to pałac architekta i majora artylerii, Jana Zygmunta Deybla' . Według ustaleń Zofii Rejman, w 1786 r. parcel było już więcej (90). Na terenie jurydyki stało wówczas 41 kamienic, 37 dworków, 10 pałaców i 2 kościoły ${ }^{10}$. Najgęściej zabudowana była strona nieparzysta ulicy Leszno, gdyż

${ }^{8}$ Rejman Z. 1985, s. 105.

9 Kwiatkowski M. 1989, s. 79; por. „Kurier Warszawski”, 1875, nr 114, s. 2 i n. Zamieszczono tam krótką, anonimową notkę na temat dziejów nieruchomości nr 720. Po Deyblu pałac ten należał do malarza Smuglewicza, nie wiadomo jednak, czy do Franciszka, czy do Antoniego. Następnie był on w rękach starosty sandomierskiego, Józefa Salezego Ossolińskiego, potem bankiera Fryderyka Kabryta, później zaś biskupa żmudzkiego, Stefana Giedroycia.

${ }^{10}$ Rejman Z. 1985, s. 66-68. 

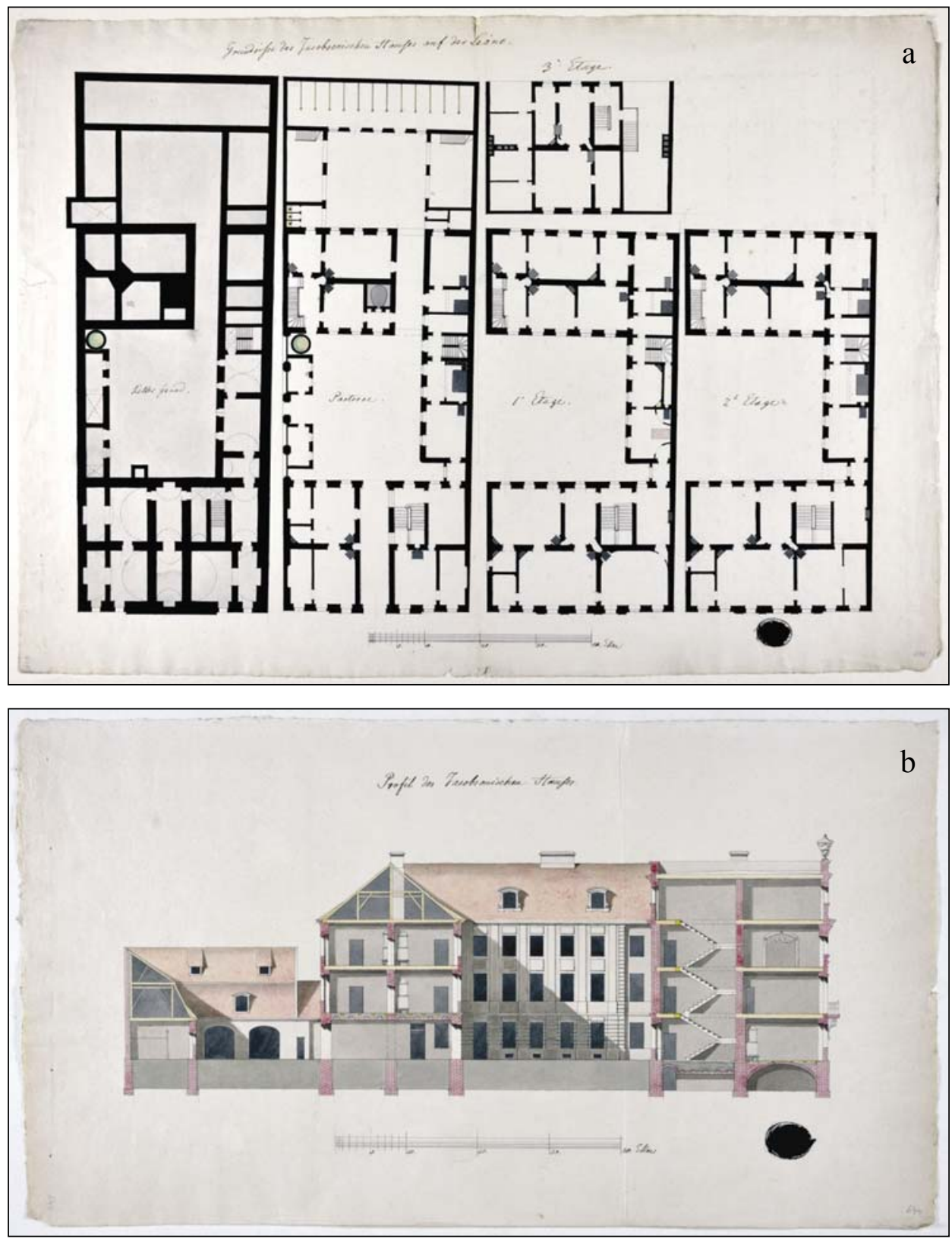

Ryc. 2. Plan (a) i przekrój podłużny (b) siedziby Jacobsonów na Lesznie, autor i data nieznani (Biblioteka UW, Gabinet Rycin, sygn. inw. G.R., nr 2337 i 2338)

Fig. 2. A floor plan (a) and a horizontal section (b) of Jacobson's house in Leszno (Warsaw), author and date unknown (Collection of Prints of the University of Warsaw, inventory G.R., nos 2337 and 2338) 
na odcinku od Rymarskiej do Orlej zarejestrowano wówczas 13 zabudowanych posesji, od Orlej zaś do Solnej było ich $12^{11}$. Ulica Solna została wytyczona w 1766 r., a Orla w 1779 r. ${ }^{12}$ Za Orlą, pod nr 726, usytuowany był pałac, stanowiący własność Jadwigi z Gomolińskich Dzierzbickiej, wojewodziny łęczyckiej. Został on przejęty od Grzegorza Dzierzęckiego za dług wartości 4000 czerwonych złotych, który zaciągnął u jej męża ${ }^{13}$. Następny numer hipoteki -725 zajmował „mały drewniany dworek, należący niegdyś do Pimingerów, a po śmierci Franciszka Pimingera sprzedany przez jego żonę Christianowi Wilhelmowi [syn Joachima Fryderyka — E.M., D.G.]

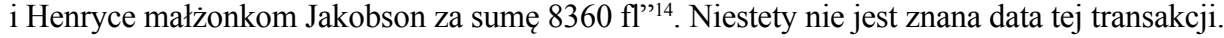

Kolejna działka — o numerze 724 opisana była w taryfie podatkowej z 1770 r. dość lakonicznie: „Leszno, nr hip. 723 i 724 Jacobsona” ${ }^{15}$. Zapis z innego, nieco późniejszego rejestru (z 1784 r.), jest bardziej szczegółowy: „nr hip. 724 wjazd i kamienica imć Jacobsonowy gdzie cerkiew J.Wielm. posła rosyjskiego, sklepów 3, kondyg. 1, łokci 39"'16. W dokumencie z $1790 \mathrm{r}$. stwierdzono, że to „kamienica o jednym piętrze, /okien 6/, z facjatką /1 okno/, z oficyną i drewnianymi budynkami gospodarczymi" ${ }^{17}$.

Właścicielem obu działek był Joachim Fryderyk Jacobson. Po raz pierwszy wzmiankowano go w styczniu $1753 \mathrm{r}^{18}$ Znany jest odpis z hipoteki pruskiej z roku 1800, w którym jako jouvelier występuje pod datą 3 lutego $1753 \mathrm{r}$. Wtedy to za kwotę 430 czerwonych złotych nabył nieruchomość pod nr $724^{19}$. W 1761 r. wybrany został starszym Zboru Ewangelicko-Augsburskiego ${ }^{20}$, w 1772 r. nabywa za kwotę 470 czerwonych złotych działkę Leszno nr $723^{21}$, a w roku 1778 zostaje przyjęty do prawa miejskiego Warszawy ${ }^{22}$. Od roku 1770 pełni funkcję nadwornego jubilera króla Stanisława Augusta Poniatowskiego. Wykonywał też biżuterię dla hetmana wielkiego koronnego, Jana Klemensa Branickiego i hetmana wielkiego litewskiego, Michała Kazimierza Radziwiłła „Rybeńki”. Nieznana jest data jego śmierci ${ }^{23}$. Nie ma pewności, czy wymieniony w zapiskach komór celnych Jacobson jest tożsamy z jubilerem Joachimem Fryderykiem ${ }^{24}$. Gdyby tak było, to świadczyłoby o bezpośrednich kontaktach gospodarczych z zagranicą, a bliżej nam nieznana działalność kupiecka przysparzałaby mu dodatkowych środków finansowych.

11 Rejman Z. 1985, s. 71-73.

12 Rejman Z. 1985, s. 71 i 73.

13 Rejman Z. 1985, s. 71.

14 Rejman Z. 1985, s. 73.

15 Taryfa Posesji. 1963, s. 497.

${ }_{16}$ AGAD, WE, nr 29a. Chodzi tu prawdopodobnie o łokieć warszawski o długości 59,6 m. Posłem rosyjskim był wtedy Otto Magnus von Stackelberg.

17 AGAD, WE, nr 24.

18 Gintyłówna R. 1969, s. 18; Otto L. 1881, s. 23; Kowecka E. 1987, s. 78.

19 APW, Hipoteka warszawska, nr 724 [830 A, t. 1], Summariusz dokumentów, k. 1.

${ }^{20}$ Otto L. 1881, s. 25. Na zebraniu Zboru Ewangelickiego, które odbyło się w pałacu Teppera 6 lipca 1761 r., wybrany został jednogłośnie starszym Zboru.

${ }^{21}$ APW, Hipoteka warszawska, nr 723, Summariusz dokumentów, k. 1.

22 AGAD, WE, nr 749, Album Civitatis Varsavie, s. 49-50, zapis 3: Jacobson Joachimus Fridericus /famatus/ 1778, 8 Augustii Jubiler i zlotnik. Famatus Joachimus Fridericus Jacobson Aurifex hic Varsaviae oriundus ad recommendationem Famati Francisci Schylter Civis Varsaviensis et Seniores Contuberny Aurificum coram prastito fidelitatis et obosdientiae juramento jus Civile C.E Ant. V Hodie supra de acta Suscepit ad libertatis immunitates et privilegia auibus ceteri Civis gaudeat est ad missus literas legitimi ortus sui se quovis tempore pedetu et pos- posesionem intra annum justa resoluitionem judiciorum S.R. Majestatis Assess, hac in Civitate sive illius Suburbi se acguisitur obtulit et declaravit, cyt. za: Teki E. Łopacińskiego, s. 11, w zbiorach Narodowego Instytutu Dziedzictwa.

${ }^{23}$ Gintyłówna R. (1969, s. 18) uważa, że zmarł prawdopodobnie pod koniec 1786 r. Według niej ostatnim jego dziełem był złoty kielich wykonany w 1786 r. dla katedry gnieźnieńskiej. Szulc E. (1989, s. 231) podaje datę 1776 r. W 1792 r. ciało J.F. Jacobsona zostało ekshumowane ze starego cmentarza ewangelickiego i złożone na nowym, w alejce 9, nr 38. Kowecka E. (1987, s. 79) przypuszcza, że jego śmierć nastąpiła ok. 1779 r.

${ }^{24}$ Grochulska B. 1980, s. 139. Mógł to być także któryś z jego synów. 
Żoną Joachima Fryderyka była Magdalena Wilhelmina z Kramerów. Autor krótkiego biogramu Joachima Fryderyka, E. Szulc, wymienił ich dzieci: Zofię Karolinę, drugą żonę księgarza i wydawcy Michała Grolla (po 1776 r.), oraz Chrystiana Wilhelma, urodzonego 6 września 1750 r. oraz jeszcze jednego syna, Henryka ${ }^{25}$. Chrystian Wilhelm Jacobson wymieniany jest w źródłach pisanych w latach 1776-1792, a ostatnia wzmianka (z 6 stycznia 1792 r.) dotyczy potwierdzenia nadanego mu rok wcześniej herbu Jedlina ${ }^{26}$. Tak jak ojciec wykonywał wyroby jubilerskie dla magnatów ${ }^{27}$ i był członkiem loży masońskiej „Le Parfait Silance” w latach 1780-1783. W jej spisach tytułowano go jako marchand jouallier ${ }^{28}$. Trzecim jubilerem o tym nazwisku był Fryderyk. Uważa się go za syna Joachima Fryderyka i brata Chrystiana Wilhelma ${ }^{29}$. W inwentarzu pośmiertnym spisanym 23 grudnia 1786 r. przez wdowę, Joannę Wilhelminę z Grixmajerów, odnotowano nieletnie wówczas dzieci: Joachima, Fryderyka, Joannę, Karolinę, Wilhelminę i Julianę Fryderykę ${ }^{30}$.

Na działce położonej bardziej na zachód, pod numerem 723, w 1784 r. stał budynek opisany jako kamienica dwukondygnacjowa i siedmioosiowa: „Leszno, nr hip.723 Kamienica Szl. Jakubsona Jubilera z murem od ogrodu, okien 7, kondygnacji 2, łokci od frontu $65^{\prime \prime 31}$. Potwierdzeniem istnienia budynku już wtedy jest akwarela Zygmunta Vogla z roku 1785/1786 ${ }^{32}$. Na podstawie późniejszego zapisu — z 1790 r., gdy część tutejszych zabudowań wynajął książę Kalikst Poniński, wiadomo o głównym podziale ówczesnych wnętrz i ich przeznaczeniu. Najemca zajął całe pierwsze piętro, tj. siedem pokoi, a także kilka izb na dole, a ponadto stajnie, spiżarnie i piekarnię, za sumę 400 czerwonych zł rocznie ${ }^{33}$.

W czasach stanisławowskich przedstawiciele najzamożniejszych rodzin mieszczańskich, oglądający niemal codziennie magnackie rezydencje, wznosząc własne domy naśladowali styl życia elit. Przypomnijmy siedziby Piotra Teppera na Miodowej i Piotra Blanka na Senatorskiej. Podobny charakter miał również dom Jacobsona, który zdaniem Marka Kwiatkowskiego był budowlą na pograniczu kamienicy i pałacu ${ }^{34}$. Analiza zachowanych w Gabinecie Rycin Uniwersytetu Warszawskiego rysunków architektonicznych przedstawiających rzuty poziome kondygnacji oraz przekrój poprzeczny budowli zdaniem Jolanty Putkowskiej wskazuje, że autorem projektu rezydencji Jacobsona był autor wielu klasycystycznych budowli w Warszawie, Szymon Bogumił Zug. Jednakże ani data wzniesienia tej siedziby, ani autor projektu nie są dokładnie znane ${ }^{35}$.

Na działce nr 723 postawiono obszerny budynek. Niektórzy historycy sztuki określają go jako kamienicę, my uważamy jednak, że to pierwszy w Warszawie pałac mieszczański. Budowla miała wymiar 18,70 m szerokości na 37,95 m długości, za nią zaś, w głębi działki, usytuowano dziedziniec gospodarczy. Gmach miał trzy kondygnacje, w części był podpiwniczony. Na par-

25 Szulc E. 1989, s. 232.

${ }^{26}$ Gintyłówna R. 1969, s. 18. Kowecka E. 1987, s. 79-80.

${ }^{27}$ Kowecka E. 1987, s. 80.

28 Hass L. 1980, s. 536.

29 Kowecka E. 1987, s. 80-81.

30 AGAD, SW, nr 328, s. 20-21.

31 AGAD, WE, nr 29a.

32 Sroczyńska K. 1969, s. 72 i 142.

${ }^{33}$ Rejman Z. 1985, s. 73 i n. Książę Poniński, podobnie jak Chrystian Wilhelm, był członkiem loży masońskiej „Le Parfait Silance”.

34 Kwiatkowski M. 1989, s. 240.

35 Por. Putkowska J. 1997, s. 88; Gintyłłówna R. 1969, s. 10. Projekt wiązano wcześniej z Janem Christianem Kamsetzerem (por. Łoza S. 1954, s. 140) lub widziano w nim pracę wspólną Jakuba Fontany i Szymona Bogumiła Zuga (por. Kwiatkowski M. 1973, s. 175-176). Autor ten uważał, że Jakub Fontana jest domniemanym autorem projektu, a dokończył go S.B. Zug (Kwiatkowski M. 1989, s. 240). Z kolei Ryszard Mączyński (2016, s. 499) datuje budowę na lata siedemdziesiąte XVIII w., a za autora uznaje S.B. Zuga. 
terze, na osi budynku wytyczono przejazdową sień, a po obu jej stronach, w układzie dwutraktowym, architekt zaplanował sklepy lub kantory z zapleczami i klatkę schodową prowadzącą aż na poddasze. Na pierwszym piętrze od frontu przewidywane było mieszkanie właściciela z reprezentacyjną klatką schodową i schodami gospodarczymi. Na drugim piętrze, o układzie powtórzonym za niższą kondygnacją, wydzielono pomieszczenia przeznaczone na oddzielne mieszkanie pod wynajem. Na poddaszu znalazły się kolejne cztery pomieszczenia ${ }^{36}$. Parter połączony był łącznikiem z wąską jednotraktową oficyną. Parter oficyny miała zajmować kuchnia i schody prowadzące od piwnicy do drugiego piętra. Oficyna południowa, zamykająca poprzecznie dziedziniec, miała przejezdną sień oddzielającą trakt zachodni (przewidziany dla służby) od dwutraktowej części wschodniej (zajmowaną przez pracownię złotniczą i schody obsługujące tę część kamienicy). W piętrowej oficynie miało też mieścić się samodzielne mieszkanie do wynajęcia, z odrębną kuchnią. Sień prowadziła na wewnętrzny dziedziniec, który miał także drugi wjazd obudowany dwoma parterowymi kordegardami. Na dziedzińcu znajdowała się też studnia. Drugi dziedziniec, do którego wchodzono przez sień w oficynie, był otoczony kilkoma zabudowaniami — stajni na 13 koni, dwóch wozowni i ubikacji ${ }^{37}$.

Analizę stylistyczną fasady frontowej i wystrój wnętrza przedstawiła J. Putkowska ${ }^{38}$. W tym miejscu można powtórzyć cechy wyróżniające ten projekt: wysunięte ryzalitowo trzy środkowe osie przechodzące $\mathrm{w}$ belweder, arkadowy przejezdny portal w przyziemiu, na piętrze joński porządek pilastrów i balkon oparty na wolutowych wspornikach, a także dekoracyjne wazy ustawione na narożnikach attyki. Dostrzegano także, że układ fasady był zbliżony do innego dzieła S.B. Zuga - kamienicy Małachowskiego przy ul. Senatorskiej nr $8^{39}$. Wewnątrz zwracał uwagę wystrój dwóch sal na pierwszym piętrze omawianego budynku. Ich ściany były ozdobione wysokimi białymi cokołami ze złoceniami i obiciami z tkanin, fryzem plecionkowym lub listwą z plecionką. Wytworności dodawały obicia z tkanin i lustra z malowidłami pejzażowymi. Trzeba wspomnieć o kominku z piaskowca, z lustrem w ozdobnej złoconej ramie oraz o półkolistej niszy wyłożonej barwnym stiukiem $\mathrm{z}$ wsuniętym w nią piecem, a także o rozecie otoczonej dekoracją roślinną. To elementy dekoracyjne wnętrz pałacowych, a wśród nich rozmaite detale architektoniczne, wskazywały bardziej na autorstwo S.B. Zuga. Były to: ornament plecionkowy z rozetkami, liście dębu przepasane krzyżującą się wstążką, girlandy na tle płyciny z ukośnymi wykrojami, podwieszone chusty, okrągłe guzy, cekiny i meander, wieniec i girlandy laurowe, proste i ukośne żłobiny, girlandy z róż, pionowo uszeregowane liście akantu w fasecie, rytony po obu stronach wazy z medalionami i łbami baranów, wstęgi przyczepione okrągłym guzem, konsolki, ustawione parami, maska ludzka ${ }^{40}$.

W inwentarzu pośmiertnym Fryderyka Jacobsona z 1786 r. odnotowano kilka różnych kategorii przedmiotów, w tym „,ruchomości różne”. Jedna z nich to meble, będące — jak sądzimy — dobrym wyznacznikiem podążania za obowiązującym wtedy stylem w wyposażeniu rezydencji magnackich. Czy znajdowały się one na Lesznie? Nie mamy pewności. Wydaje się jednak, że ich kolejność w rejestrze nie była przypadkowa; może spisano je w porządku odpowiadającym ich usytuowaniu we wnętrzach pałacowych. Wymieniono zatem: „1 kantorek jesionowy ciemno bejcowany - f[lorenów]. 90, 1 d.[itto] ordynaryjny - f. 63; 1 komoda $\mathrm{z}$ aufszacem [nadstawką — D.G., E.M.] — f. 54, 2 d.[itto] bez aufszaca — f. 126”41. Mogły one stać w pomieszczeniach, w których wyrabiano biżuterię. $Z$ kolei w reprezentacyjnej części siedziby znajdowały się przypuszczalnie: „1 kanapa i 6 krzeseł ordynaryjnych — f. 108; $1 \mathrm{~d}$.[itto] podlejsza - f. 72, 6 krzeseł - f. 54, 2 wielkie stoły jadalne f. 72, 1 d.[itto] okrągły — f. 15,

\footnotetext{
36 Putkowska J. 1997, s. 88 i n.

37 Putkowska J. 1997, s. 91 i n.

38 Putkowska J. 1997, s. 91-92 i n.

39 Gintyłówna R. 1969, s. 11.

${ }^{40}$ Gintyłłówna R. 1969, s. 12.

${ }^{41}$ AGAD, SW, nr 328, k. 22v.
} 
1 d.[itto] sosnowy - f. 8”42. Do urządzenia sypialni mogły służyć: „1 stolik nocny drzewa różowego z kamiennym blatem f. 36, 1 d.[itto] jesionowego drzewa $\mathrm{z}$ marmurowym blatem f. 18, 2 małe bejcowane stoliki - f. 18, 3 d.[itto] jeszcze mniejsze - f. 9"43.

Zgodne z ówczesną modą sprzęty takie jak kanapa i komoda stały np. we wnętrzach Zamku Królewskiego w 1769 r., m.in. w mieszkaniu sekretarza królewskiego Rembielińskiego była kanapa „warszawska” ${ }^{44}$. Zdaniem Hanny Szwankowskiej, własnością średniozamożnego mieszczaństwa były głównie krzesła obite suknem, trypą lub skórą, do rzadkości zaś należały garnitury składające się z kanapy i sześciu krzese ${ }^{45}$. W siedzibach magnackich lub biskupich nieodzowne były liczne meble do siedzenia. W pałacu Branickich w 1771 r. tylko w trzech przedpokojach odnotowano 42 krzesła $^{46}$. Biskup warmiński Adam Stanisław Grabowski w swej warszawskiej rezydencji w 1765 r. miał aż trzy komplety złożone z kanapy i tuzina krzeseł ${ }^{47}$. Rezydujący także w Warszawie, w pałacu wynajmowanym od spadkobierców Słonimskiego przy ulicy Miodowej, biskup chełmski Maciej Garnysz w roku 1790 dysponował trzema kanapami w kolorach karmazynowym, zielonym i żółtym, a także trzema kompletami krzeseł, z czego 20 sztuk obitych było czerwonym adamaszkiem, 24 płótnem, a 10 określono jako żółte ${ }^{48}$.

Do rodziny Jacobsonów należała też działka po drugiej stronie ulicy Leszno, oznaczona nr hipotecznym 669. Niejasny jest fragment opracowania Zofii Rejman, która napisała: „Na samym rogu Karmelickiej stał dworek drewniany, własność chirurga Jana Szyszczyńskiego, a obok niego wznosił się pałac Piotra Teppera, bankiera warszawskiego, graniczący znów z pustym placem Kazimierza Krasińskiego, oboźnego wielkiego koronnego [...] Pałac Piotra Teppera (nr hip. 669) drogą donacji w 1784 r. dostał się Piotrowi Fergusonowi Tepperowi (młodszemu), a ten w kilka lat później sprzedał go małżonkom Jakobsonom, uzyskując ze sprzedaży sumę 1800 czerw. zł. Jakobsonowie przystąpili zaraz do rozbierania bliżej nie określonej, zniszczonej fabryczki, która stała na tym placu, a gdy spadający z góry gruz uszkodził dach na dworku Szyszczyńskiego,

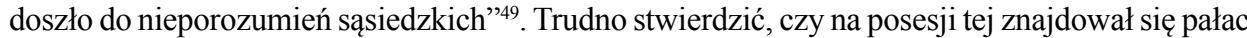
Teppera, który przecież posiadał rezydencję przy Miodowej, czy raczej jakieś zabudowania o charakterze gospodarczym. Poza tym, dlaczego Jacobsonowie kupowaliby kolejną rezydencję?

W rejestrze z 1807 r. działki o numerach hipotecznych 723 i 724 określono jako „Jakubsonowy"50. Tak sformułowany zapis utrudnia jednoznaczną identyfikację właściciela. W lutym 1820 r. w ogłoszeniu publicznym wydanym przez Komisję Województwa Mazowieckiego wezwano osoby posiadające tytuł własności do nieruchomości pod numerem $723^{51}$. 5 maja tego roku przed komisję stawił się Jakub Wilhelm Zügler, dzierżawca dóbr rządowych klucza Gaszyna w obwodzie wieluńskim, w województwie kaliskim, w imieniu żony — Karoliny Jacobson. Przedstawił on protokół z hipoteki pruskiej z czerwca 1805 r. wskazujący, że posesja ta należała do Magdaleny Wilhelminy z Kramerów Jacobsonowej. Zeznał także, że po śmierci Magdaleny został przeprowadzony dział i „taż nieruchomość na wiele głów to jest Córki i Synów, którzy częścią już nie żyją i po nich tylko następni sukcesorzy znajdują się”. Poinformował, że wyznaczeni zostali też pełnomocnicy do realizacji tych postanowieńn ${ }^{52}$. Przed sądem stawił

${ }^{42}$ AGAD, SW, nr 328, k. 22v.

${ }^{43}$ AGAD, SW, nr 328, k. 22v. Karaś.

${ }^{44}$ Inwentarz Zamku. 1907, s. 129. Kanapy mieli cukiernik Johann Rychter (Richter) i marszałek Kazimierz

45 Szwankowska H. 1963, s. 329-331.

46 Bartczakowa A., Malinowska I. 1974, s. 47 i n.

47 Zob. Kwiatkowski M. 1975, s. 107. Komplety złożone z kanapy i krzeseł miał także na zamku w Lidzbarku w 1767 r., Dygdała J. 1991, s. 131-132.

48 Główka D. 1996, s. 182.

49 Rejman Z. 1985, s. 85.

50 Taryfa. 1807 , s. 25.

${ }^{51}$ APW, Hipoteka warszawska, nr 723, k. 21

52 APW, Hipoteka warszawska, nr 723, k. 22. 
się również Stanisław Kryński, jako właściciel nieruchomości oznaczonej nr 725 oraz części placu pustego za domem nr 724, którą kupił w 1818 r. od spadkobierców rodziny Jacobson ${ }^{53}$. Na podstawie analizowanych archiwaliów (z kwietnia 1818 r. oraz czerwca 1820 r.) znani są następujący spadkobiercy: Magdalena Fryderyka z Jacobsonów Ebertowa wdowa, Franciszka z Jacobsonów Kortonowa, Henrietta z Jacobsonów Dreysigowa, wdowa, Jan Henryk August Dreysig, zamieszkały przy Lesznie $723^{54}$.W kolejnej taryfie z roku 1821 właścicielem obu opisywanych nieruchomości był Zanelli, wymieniany tylko z nazwiska ${ }^{55}$.

W dokumencie z 21 stycznia 1818 r. wystawionym przez Teodora Czempińskiego, zapisano, że Anna Henrietta Elżbieta Jacobson, córka zmarłego Henryka Jacobsona i Salomei z Wojnickich, pasierbica Wincentego Zanellego, zamierzając wyjść za mąż za Teodora Mrozowskiego, lekarza drugiej dywizji piechoty Wojska Polskiego, ,żadnej od Rządu Krajowego jako wdowa po nim pozostała pomocy i alimentacji żądać nie będzie" ${ }^{56}$. Z tegoż aktu wynika, że ojczym Anny Henrietty mieszkał przy ul. Senatorskiej. W wyroku Trybunału Cywilnego z dnia 13 października 1823 r. wymienieni są natomiast: Fryderyka z Jacobsonów Hasenkampf i jej mąż Fryderyk Hasenkampf, major wojsk pruskich, oraz spadkobiercy Henryka Jacobsona, czyli Salomea z Wojnickich primo voto Jacobson, wtedy już wdowa po Wincentym Zanelli, Wilhelmina Karolina Magdalena z Jacobsonów Zygler [Zügler] i jej mąż Jakub Zygler [Zügler], Henrietta Anna z Jacobsonów Mrozowska wdowa, Franciszka Kortunowa, Elżbieta Zügeher, sukcesorowie Fryderyki Magdaleny Ebertowej, czyli Wilhelmina Dorota z Ebertów Bartoldowa wdowa, Karolina Augusta z Diehlów Tetzmanowa, pastor Karol Diehl i jego nieletnie córki (Ludwika Emilia i Amalia Maria) oraz syn (Adolf Fryderyk), ponadto: nieletnia Adelajda Jacobson wraz z matką Kunegundą Franciszką z Müllerów Jacobsonową, wdową po Karolu Jacobsonie, Teofil Jacobson, syn Krystyny Wilhelminy Jacobson, sukcesor Joanny Eleonory z Jacobsonów Dreysig i Krystianny z Jacobsonów Dreysig. Nakazano im sprzedaż nieruchomości na drodze licytacji. W roku 1823 omawiana posesja została oszacowana na sumę 104394 zł i 22 1/2 grosza ${ }^{57}$.

W latach dwudziestych XIX w. nastąpił kres praw własnościowych do obydwu nieruchomości przy Lesznie — nr 723 i 724 przez ród Jacobsonów.

Adresy Autorów:

dr hab. prof. IAE PAN Dariusz Główka

Instytut Archeologii i Etnologii PAN

Al. Solidarności 105

00-140 Warszawa

glowka@iaepan.ed.u.pl

ORCID: 0000-0002-1633-5505

dr hab. prof. IAE PAN Elżbieta Mazur

Instytut Archeologii i Etnologii PAN

Al. Solidarności 105

00-140 Warszawa

pasiam5@gmail.com

ORCID: 0000-0002-7757-6708

53 APW, Hipoteka warszawska, nr 723, k. 23; APW, Hipoteka warszawska, nr 723, Summariusz dokumentów, k. 2, 4 i n. Zakupiony plac miał 30 łokci na szerokość oraz 111 długości, a graniczył z działkami nr 726, należącymi do Gorzyńskiej kasztelanowej i Danglów.

54 APW, Hipoteka warszawska, nr 723, Summariusz dokumentów, k. 3 i 4.

55 Taryfa. 1821.

56 APW, Kancelaria notarialna Teodora Czempińskiego, nr 29, akt nr 3739.

57 APW, Hipoteka warszawska, nr 723, Summariusz dokumentów, k. 9-13. 


\section{BIBLIOGRAFIA}

\section{Źródla archiwalne}

AGAD [Archiwum Główne Akt Dawnych], WE [Księgi miejskie Warszawa Ekonomiczne], nr 29 a, Taryfa possessji m. St. Warszawy 1784.

AGAD [Archiwum Główne Akt Dawnych], WE [Księgi miejskie Warszawa Ekonomiczne], nr 24, Wymiary possessyi i Gruntów m. St. Warszawy z r. 1790.

AGAD [Archiwum Główne Akt Dawnych], WE [Księgi miejskie Warszawa Ekonomiczne], nr 749, Album Civitatis Varsavie.

AGAD [Archiwum Główne Akt Dawnych], SW [Księgi miejskie Starej Warszawy], Acta officii consularis C.A.V. inventariorum, exdivisionum et complanationum, nr 328, Oblata inventarii fatis olim nobilis Fridericii Jacobson substantiaes, s. 20-26.

APW [Archiwum Państwowe w Warszawie], Hipoteka warszawska, nr 723, nr 724 [830 A, t.1], Summariusz dokumentów, k. 1 .

APW [Archiwum Państwowe w Warszawie], Kancelaria notarialna Teodora Czempińskiego, nr 29, akt nr 3739 .

\section{Źródla i opracowania publikowane}

Bartczakowa Aldona, Malinowska Irena. 1974. Pałac Branickich, Warszawa.

Dziewulski Stefan, Radziszewski Henryk. 1913. Warszawa, t. 1: Dzieje miasta; Topografia; Statystyka ludności, Warszawa.

Dygdała Jerzy. 1994. Adam Stanisław Grabowski (1698-1766). Biskup, polityk, mecenas, Olsztyn.

Gintyłówna Romana. 1969. „Pałac i kamienica Jacobsonów”, Warszawa (maszynopis w archiwum Państwowego Przedsiębiorstwa Pracowni Konserwacji Zabytków).

Główka Dariusz. 1996. Być biskupem i ministrem. Majątek ruchomy biskupa chetmskiego i podkanclerzego Macieja Garnysza (1790 r.), „Kwartalnik Historii Kultury Materialnej”, R. XLIV, nr 2, s. $177-183$.

Grochulska Barbara. 1980. Warszawa na mapie Polski stanisławowskiej, Warszawa.

Hass Ludwik. 1980. Sekta farmazonii warszawskiej, Warszawa.

Inwentarz Zamku. 1907. Inwentarz Zamku Jego Królewskiey Mości y Rzeczypospolitey Warszawskiego nad Wista leżącego z zlecenia Przeswietney Rzeczypospolitey Skarbu Koronnego Kommissyi przez niżey podpisanego $z$ wyrażeniem Appartamentow y innych mieszkań tudzież memblow y wszelkich należytości Roku 1769 spisany. wyd. K. Marcinkowski, „Przegląd Historyczny”, t. 5, z. 1, s. 110-138.

Kowecka Elżbieta. 1987. Z dziejów jubilerstwa warszawskiego w XVIII wieku. Prace Joachima Fryderyka Jacobsona dla Jana Klemensa Branickiego, „,Kwartalnik Historii Kultury Materialnej”, R. XXXV, nr 1, s. 77-92.

Kwiatkowski Marek. 1973. Kamienice warszawskie drugiej połowy XVIII w. Próba systematyzacji, [w:] Warszawa XVIII wieku, z. 2, red. J. Kowecki, Warszawa, s. 161-217.

Kwiatkowski Marek. 1975. Pałac Teodora Potockiego i Mennica Jego Królewskiej Mości, „Rocznik Warszawski”, R. XIII, s. 97-133.

Kwiatkowski Marek. 1989. Architektura mieszkaniowa Warszawy. Od potopu szwedzkiego do Powstania Listopadowego, Warszawa.

Lechman Johann Georg, Bach Joseph. 1809. Plan miasta Warszawy. Plan von der Stadt Warschau, Drezno.

Łoza Stanisław. 1954. Architekci i budowniczowie w Polsce, Warszawa.

Mączyński Ryszard. 2016. Zug Simon Gottlieb, [w:] Stownik architektów i budowniczych środowiska warszawskiego XV-XVIII wieku, red. P. Migasiewicz, H. Osiecka-Samsonowicz, J. Sito, Warszawa, s. 498-509.

Otto Leopold. 1881. Przyczynek do historii Zboru Ewangelicko-Augsburskiego w latach 1650-1781, Warszawa.

Putkowska Jolanta. 1997. Dom bogatego mieszczanina gdańskiego i warszawskiego w II połowie XVIII wieku — różnice i podobieństwa, [w:] Mieszczaństwo gdańskie. Sesja naukowa „,Mieszczaństwo gdańskie”, 21-23.11.1996, Gdańsk 1997, red. S. Salmonowicz, Gdańsk, s. 81-107. 
Rejman Zofia. 1985. Jurydyka Leszno w czasach Stanisława Augusta Poniatowskiego, część I, „Rocznik Warszawski”, t. 18, s. 61-119.

Rejman Zofia. 1987. Jurydyka Leszno w czasach Stanisława Augusta Poniatowskiego, część II, „Rocznik Warszawski”, t. 19, s. 5-42.

Sawicki Tymoteusz. 1925, Jurydyki i ratusze Warszawy, „Kronika Warszawy”, z. 11, s. 2-12.

Smoleńska Barbara. 1984. Przemiany struktury własności ziemskiej w okolicach Warszawy w XVI-XVIII wieku, „Rocznik Mazowiecki”, t. 8, s. 87-107.

Sroczyńska Krystyna. 1969, Zygmunt Vogel. Rysownik gabinetowy Stanisława Augusta. Wrocław-Warszawa.

Szulc Eugeniusz. 1989. Cmentarz ewangelicko-augsburski w Warszawie, Warszawa.

Szwankowska Hanna. 1963. Wnętrza warszawskich domów w XVIII wieku, „Kwartalnik Historii Kultury Materialnej”, R. VIII, nr 3, s. 313-335.

Taryfa. 1807. Taryffa domów miasta Warszawy dla wygody pobliczney wydana nakładem S. Z. roku 1807 w miesiącu wrześniu [...], Warszawa.

Taryfa. 1821. Taryffa domów miasta stołecznego Warszawy dla wygody publicznéj nowo wydana, z dołączeniem przedmieścia Pragi i domów za rogatkami będących, tudzież opisu historycznego tey stolicy, Warszawa.

Taryfa Posesji. 1963. Taryfa Posesji Warszawy z r. 1770, [w:] Źródła do dziejów Warszawy, t. 1, Rejestry podatkowe i taryfy nieruchomości 1510-1770, wyd. A. Berdecka, J. Rutkowska, A. Sucheni-Grabowska, H. Szwankowska, Warszawa.

Wojtowicz Jerzy. 2017. Miasto europejskie w epoce Oświecenia i Rewolucji Francuskiej, wyd. 2, Toruń.

The history of Jacobson's residence in Warsaw in the second half of the 18 th century and the early 19 th century

Jacobson's palace is a good example of a burgher family residence in 18th-century Warsaw. A 1770 tax roll lists the Jacobsons as the owners of properties registered as nos 723 and 724 in the jurydyka (enclave) of Leszno. Both building lots were owned by Joachim Fryderyk Jacobson, whose name is first mentioned in sources in January 1753. He bought the property at no. 724 for 430 ducats, equalling 1290 Polish zloties, on the 3rd of February 1753. In 1761 he was elected an elder of the community of the Evangelical-Augsburg Church and in 1778 he was admitted into the municipal law of Warsaw. In 1770 he became the court jeweller of King Stanislaus Augustus Poniatowski, for whom he made orders of St Stanislaus. Among Jacobson's customers were also Jan Klemens Branicki, who ordered jewellery from him, and hetman Michał Kazimierz "Rybeńko" Radziwiłł. Jacobson died probably at the end of 1786.

Jacobson's residence represents a type that art historians describe as a cross between a palace and a tenement house. It had a spacious apartment for the owner in the front part on the first floor; it also had flats for rent with household facilities. The design is ascribed to either Jakub Fontana or Szymon Bogumił Zug, who were both architects active in Warsaw at that time. Written sources indicate that the house had three storeys. On the ground floor there was a gateway, with shops or offices on both sides, and a grand staircase leading up to the attic. The numerous rooms on the higher storeys (two on the second floor and four in the attic) might have been the living quarters of the King's jeweller's children. The house is shown in Zygmunt Vogel's watercolour, dated to $1785-86$. Both properties were owned by J.F. Jacobson's descendants until the 1820s. 